\section{Serum Enzyme Elevation in Glutethimide Intoxication}

British Medical Fournal, 1970, 3, 751

While the diagnostic usefulness of serum enzyme tests has undoubtedly been established the emphasis on their diagnostic specificities is sometimes misplaced. It is often more appropriate to interpret serum enzyme activities in the light of probable tissue injury rather than of specific diagnoses. This is illustrated by serial studies recently performed on two patients with acute glutethimide intoxication.

\section{CASE 1}

A 35-year-old woman was admitted to the Hospital of the University of Pennsylvania five hours after the ingestion of $15 \mathrm{~g}$. of glutethimide. She was in a deep coma and her temperature had fallen to $97^{\circ} \mathrm{F} .\left(36.1^{\circ} \mathrm{C}\right.$.). Gastric lavage was performed and intravenous fluid given, but hypotension $(80 / 50 \mathrm{~mm}$. $\mathrm{Hg}$ ) and oliguria (less than $20 \mathrm{ml}$./hour) developed. Extracorporeal and peritoneal dialysis over 56 hours resulted in a progressive fall in the serum glutethimide from 4.9 to $2.3 \mathrm{mg}$. $/ 100 \mathrm{ml}$. The rectal temperature fell to a minimum of $95^{\circ} \mathrm{F}$. $\left(35^{\circ} \mathrm{C}\right.$.) The coma lightened steadily and after 18 hours pressor amines and assisted ventilation were no longer required. On day 6 she was discharged to the Psychiatric Service for follow-up.

The biochemical findings were normal apart from the serum enzyme levels, of which the following were determined: alkaline phosphatase, aspartate transaminase AsT, alanine transaminase (AlT), lactate dehydrogenase (L.D.H.), 2-hydroxybutyrate dehydrogenase, and creatine kinase (C.K.). The serum glutethimide was determined by the method of Dauphinais and McComb (1965). The serum enzymes began to rise on the third day, reaching maxima about the sixth day. The most spectacular rise occurred in the serum creatine kinase, but the alkaline phosphatase was also very high. By contrast the transaminase and dehydrogenase values were only slightly raised (Fig. 1).

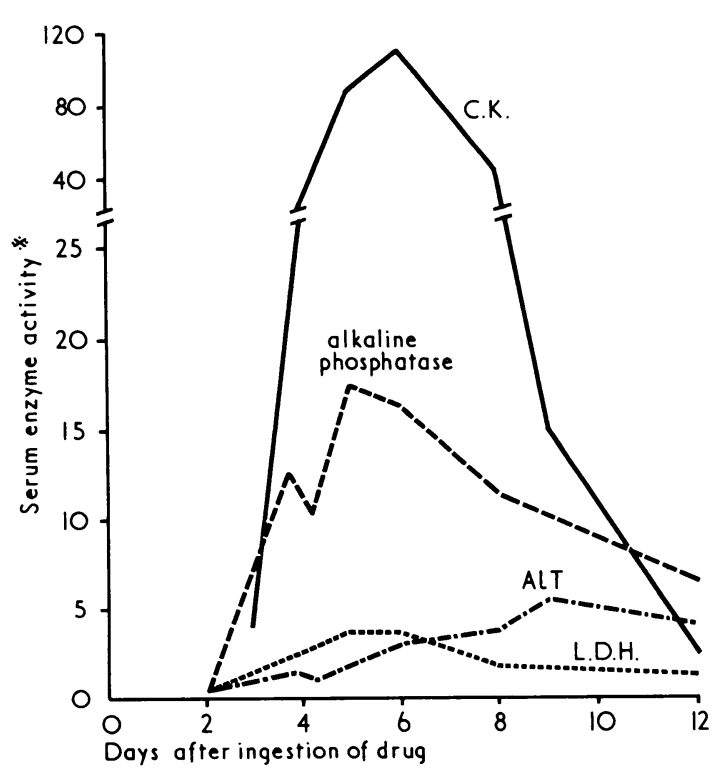

FIG. 1.-Serial determinations of serum enzymes in Case 1.

* As the individual enzymes are normally measured in different units, the values shown are expressed as multiples of the upper limit of the normal range-for example, $C$. K. at day 6 was $120 \times$ normal value.

Electrophoresis showed the creatine kinase to consist of a single cationic band of the muscle type. A single band of alkaline phosphatase activity corresponding in mobility to the intestinal mucosal enzyme was obtained on agar-gel electrophoresis, but two bands were detected with the more sensitive Cellogel (Chemetiron, Milan) technique.

The serum alkaline phosphatase was sensitive to $0.005 \mathrm{M} \mathrm{L-}$ phenylalanine, in the presence of which only $45 \%$ of the control activity could be detected (Fishman et al., 1962).

\section{CASE 2}

A woman aged 34 had a serum glutethimide level of $5.6 \mathrm{mg} . / 100 \mathrm{ml}$. after ingesting $37 \mathrm{~g}$. of the drug. After 24 hours of extracorporeal dialysis it fell to $4.5 \mathrm{mg} . / 100 \mathrm{ml}$. Though the serum creatine kinase was very high on the seventh day, the serum alkaline phosphatase showed only slight increases (96 and 63 i.u./l. on days 2 and 7 respectively).

\section{COMMENT}

The increase in serum enzyme activities after overdoses of drugs can often be attributed to hepatotoxic effects. In Case 1 , however, the alanine transaminase was only slightly affected while the creatine kinase was greatly increased. Since the former is a sensitive indicator of liver damage, while elevation of the latter is rarely associated with liver diseases, it seems that the liver was only slightly affected in this patient and that other tissues suffered major damage.

Electrophoretic studies of the serum enzyme in Case 1 showed only the single slow muscle component (Deul and Van Breeman, 1964), and it seems likely that most of the circulating creatine kinase originated in the skeletal musculature. There was no evidence of myocardial damage, and electrophoresis excluded the presence of the fast brain isoenzyme. Maclean et al. (1968) observed a rise of the serum creatine kinase in a series of patients with hypothermia, including one with glutethimide poisoning, and suggested that the enzyme originated in skeletal muscle. It is interesting to note that the patients in the present study were also hypothermic.

The pronounced rise of the serum alkaline phosphatase in Case 1 was at first thought to be due to release of the liver enzyme, but on electrophoresis it behaved like the intestinal mucosal enzyme. It also resembled intestinal phosphatase in its sensitivity to L-phenylalanine and in its electrophoretic mobility being unaffected by previous incubation with neuraminidase. Release of the intestinal enzyme might be due to chemical or mechanical trauma resulting from the ingestion of a large number of tablets.

We conclude from these studies that the increased serum creatine kinase levels are largely due to skeletal muscle damage resulting from prolonged hypothermia, and that intestinal trauma probably accounted for the rise in the intestinal phosphatase component in Case 1 . These investigations suggest that serum enzyme tests should be regarded as indicators of the site, extent, and possible nature of tissue damage rather than simply as aids to diagnosis.

\section{LEE W. HeNDERSON, M.D. \\ MARYANNE METZ, B.S. \\ J. HENRY WILKINSON,* D.SC., PH.D., M.R.C.PATH.}

Departments of Medicine and Pathology, William Pepper Laboratory, University of Pennsylvania, Philadelphia, Pennsylvania 19104, U.S.A.

* Present address: Department of Chemical Pathology, Charing Cross Hospital Medical School, London W.C.2.

\section{REFERENCES}

Dauphinais, R. M., and McComb, R. (1965). American fournal of Clinical Pathology, 44, 440.

Deul, D. H., and Van Breeman, J. F. L. (1964). Clinica Chimica Acta, 10, 276 Fishman, W. H., Green, S., and Inglis, N. I. (1962). Biochemica et Biophysica Acta, 62, 363.

Maclean, D., Griffiths, P. D., and Emslie-Smith, D. (1968). Lancet, 2, 1266. 